УДК $340.15(94)$

DOI https://doi.org/10.32837/apdp.v0i85.1829

\title{
А.Ю.Иванов
}

\section{КАЗАХСКОЕ ХАНСТВО КАК ОБЪЕКТ РОССИЙСКОГО ГЕОПОЛИТИЧЕСКОГО ВЛИЯНИЯ (1465-1731 ГГ.): ИСТОРИКО-ПРАВОВОЙ АСПЕКТ}

Постановка проблемы. Экспансионистский характер внешней политики России как черта, присущая всем периодам существования этого государства, обусловливает ее основную направленность на удовлетворение стратегических интересов российской властной верхушки в тех или иных регионах мира. Одним из таких регионов постоянно была богатая на природные ресурсы и расположенная на перекрёстке торговых путей Средняя Азия. Хивинское, Бухарское и Казахское ханства - это были те государства, на завоевание которых из указанных выше соображений направляло свои усилия сначала Московское царство, а затем и Российская империя.

Особо важное место среди указанных государств российские правители отводили Казахскому ханству как приграничной территории, удобной для выхода на азиатские рынки и дальнейшего осуществления экспансии в этом регионе. Эти и другие факторы обусловливали выбор тех специфических методов и средств, которые в итоге привели к включению казахских территорий в состав Российской империи в течение XVIII - XIX вв. При этом следует учитывать, что в число объектов стратегической заинтересованности российского государства Казахское ханство попало ещё со времени его основания в 1465 г.

Историография проблемы. В историографии (дореволюционной и современной российской, советской и современной казахской) принято считать, что присоединение жузов - составных частей административной системы Казахского ханства к Российской империи в течение указанного выше периода происходило вполне добровольно и было обусловлено исключительно необходимостью поиска сильного союзника, покровителя с целью противостояния внешним врагам (Китаю, Джунгарскому ханству и другим) [12].

Сочетая эти факторы с «естественным тяготением» казахов к России, историки утверждают о якобы неотвратимости решений ханов Младшего, Среднего и Старшего жузов относительно направления прошений российскому императору о принятии их под свой протекторат $[6 ; 7 ; 10 ; 14]$. При таких условиях в трудах этих исследователей Российская империя предстает как спаситель, который предотвратил неминуемую гибель казахского народа и его этнической самобытности. При этом любые прагматические соображения российского самодержавия, направленные на удовлетворение экспансионистских намерений, эти ученые в большинстве не отмечают. Они вместо этого прибегают к яркому описанию «угрожающего» и «отсталого» положения казахского государства накануне его включения в состав России.

Изложение основного материала. Среднеазиатский регион всегда привлекал внимание московского государства как экономически и стратегически важный форпост для выхода на азиатский рынок. Вышедшие из-под монгольского влияния 
лишь в середине XIV в., московские князья считали себя потомками Чингисхана, претендующими на восстановление империи в былых границах. Соответственно, ни одну из азиатских стран Москва не рассматривала в качестве своего союзника, все они являлись потенциальными объектами экспансии. Ввиду этих факторов чрезвычайно актуальным для Московского княжества стал захват Казахского ханства, образовавшегося в 1465 г. [5; 8]. Особенности географического положения ханства, децентрализованный характер его власти и специфика кочевого быта делали это государство весьма выгодным и уязвимым объектом московской экспансии.

Исходя из обозначенной периодизации, очевидно, что с конца XV в. Московское царство, а затем и Российская империя взяли курс на дестабилизацию политической ситуации в Казахском ханстве, поскольку существование сильного централизованного казахского государства уже не соответствовало российским стратегическим целям. Весьма показательно, что в историографии для характеристики изучаемого периода параллельно используются термины «русско-казахские» и «казахско-российские» отношения.

Обзор соответствующих работ позволяет утверждать, что первый термин, несмотря на его этимологию, применяется историками при характеристике захватнической политики российского самодержавия в отношении казахов. Вторым термином обозначается «естественное тяготение» казахского государства к России. При этом следует учитывать, что в обоих указанных случаях Казахское ханство рассматривается не как полноценный субъект международных отношений, а исключительно как мишень российских экспансионистских устремлений.

Казахская государственность стала привлекать внимание московских правителей ещё со времени её зарождения. Так, среди государственных документов Московского княжества второй половины XV в. сохранились сведения о правлении тогдашнего казахского хана Касыма. Из более позднего времени известен также трактат «Книга и списки казатцкие при Косыме-царе» (примерно между 1575-1584 гг.).

Кроме этого, известно, что несколькими десятилетиями ранее московитами был составлен «Дорожник» - обширный справочник, содержавший сведения этнографического характера о местонахождении казахских земель, родах занятий местных жителей, особенностях их питания, традиционной одежде, нравах, обычаях и отношениях с Московским царством.

Помимо этого, московские правители систематизировали сведения о казахской степи, получаемые от иностранных послов (С. Герберштейна, А. Дженкинсона и других), а после завоевания близлежащих к Казахскому ханству Казанского (1552 г.) и Астраханского (1554 г.) ханств начали регулярно направлять с этой же целью и собственные посольства к казахам.

Значительный массив сведений о жизни казахов царское правительство получало от правителей граничащей с ними Ногайской орды, а также от своих послов в ней, среди которых важную роль играла деятельность Д. Губина, Б. Доможирова, С. Мальцева.

Во время активизации дипломатических отношений между Московским царством и Казахским ханством ряд представителей последнего (преимущественно торговцы) переселялись в Москву и также предоставляли важные сведения о своём 
государстве. Самым значимым в этом плане был трактат К. Жалаира, изданный в 1602 г. и известный в историографии под названием «Сборник летописей», дававший подробные сведения о казахских национальных обычаях и традициях, а также о местных правящих династиях.

Обобщением накопленных московитами этнографических, политических и прочих сведений о Казахском ханстве стала «Книга Большому чертежу» (1627 г.). Следует отметить, что в это время в связи со сближением московских и казахских границ (после завоевания Сибирского ханства в 1598 г.) в приграничных регионах летописцы стали отображать особенности политической и бытовой жизни казахов («Сибирская летопись» 1636 г.) [11].

Из вышеизложенного очевидно, что московское правительство целенаправленно и методично занималось сбором сведений о различных аспектах существования Казахского ханства. Учитывая те аспекты его жизнедеятельности, которые составляли предмет заинтересованности московского государства, можно сделать вывод, что власти последнего имели чёткие планы по распространению своего влияния на казахские территории. Накопление подробных данных об особенностях не только политической жизни казахов, но также и их быта, экономического и культурного укладов демонстрирует явно выраженный поиск направлений для поражения их этнической идентичности с целью дальнейшего покорения и захвата их территорий.

Вполне очевидно, что сведения, представленные в названных выше источниках, в большинстве далеки от научной объективности и взвешенности, поскольку собирали их не профессиональные учёные, при их сборе изначально был обозначен вектор будущего применения, что непременно накладывало отпечаток на избирательность в приёме той или иной информации.

Накопленные в таком виде сведения использовались московским государством для формирования политического курса относительно Казахского ханства, а также при планировании и проведении экспедиций накануне его захвата в первой четверти XVIII в. [2]. Тщательное предварительное изучение территории, подлежащей завоеванию, во все периоды истории являлось неотъемлемой составной частью российской экспансионистской идеологии, а также дальнейшего политического курса российского государства [9].

Следует обратить внимание на то, что активизация политики Московского царства в отношении стран Средней Азии связана с ослаблением и постепенным распадом на отдельные ханства Золотой Орды во второй половине XV - в начале XVI вв. Первыми под российский контроль попали Казанское и Астраханское ханства в 1502 г., а Сибирское ханство, которое по сравнению с ними было гораздо важнее в стратегическом отношении для Москвы, продолжало оказывать вооруженное сопротивление царскому войску.

Необходимость покорения такой ценной, богатой на природные ресурсы территории обусловила потребность в поиске достойного союзника. Главным претендентом на эту роль стал общеказахский хан Тугуме (1534-1538 гг.), чье войско московский посол Д. Губин характеризовал так: «А казахи добре сильны. Ташкент воевали, а ташкентские царевичи, говорят, дважды с ними бились, но казахи их побивали. Казахи сильные, и калмыки им поддались» [6, с. 98-99]. Также в одном 
из своих донесений царю Ивану IV он отмечал, что казахи, имея такое сильное войско, постоянно отражают нападения сибирского хана Кучума. Начиная с 1572 г., как утверждали московские хронисты, его нападения на пограничную Пермскую область стали всё более активными и угрожающими, что побудило обратиться к казахскому хану с просьбой о помощи. Новоявленный хан Таваккул (в отдельных источниках - Тевеккель) вёл длительную и ожесточенную борьбу с Кучумом, постепенно ослабляя военный потенциал сибирской армии, что привело к оккупации Сибирского ханства Россией в 1598 г. [4, с. 98].

При таких условиях Московское царство вынуждено было напоказ рассматривать Казахское ханство в качестве своего равного партнёра, предлагая ему соответствующие выгоды. Так, происходила активизация торговли между этими государствами, царь оказывал хану военную помощь для подавления местных восстаний, происходили периодические обмены посольствами. В то же время, ряд таких действий были направлен на скрытую подготовку почвы к дальнейшей экспансии на казахских территориях.

В 1594 г. Иван IV, осознавая близость времени захвата Сибирского ханства, направил посольство в Казахское ханство, уполномочив его на проведение переговоров с ханом Таваккулом с тем, чтобы склонить последнего к принятию московского подданства вместе со своим народом. В тексте царской грамоты, привезённой послами на переговоры, речь шла о том, что казахи продолжают противостояние с сибирским ханом, но уже «под нашею царьскою рукою и по нашему царьскому повелению» .

Также уже как составная часть царского войска казахи должны были завоевать Бухарское ханство и склонить его к принятию московского подданства. Ввиду столь невыгодных для Казахского ханства условий предлагаемой грамоты царские послы получили решительный отказ от казахов. Повторное посольство весной 1595 г. также не увенчалось успехом, хотя в этот раз Таваккулу и были предложены более выгодные условия союза с Москвой, но они, как и прежде, прямо предусматривали потерю Казахским ханством политической независимости.

Отношение к Казахскому ханству как к потенциальной колонии со стороны Московии проявлялось также и в характере торговых отношений между этими государствами. Её объёмы были значительными и увеличивались с каждым годом примерно на $10-15 \%$. Также в 1574 г. Иван IV своим указом разрешил казахам вести беспошлинную торговлю на территории Московского царства [1]. Торговля носила преимущественно меновой характер, и не всегда эквивалент обмена отражал реальную стоимость товаров, которые производились казахами.

Так, за изделия из чугуна россияне расплачивались лисами, что, по подсчётам историков, примерно в четыре раза было ниже их рыночных цен. В то же время, товары собственного производства россияне сбывали на казахских рынках по достаточно высоким ценам, не платя при этом никаких налогов. Историки также отмечают, что эти товары были самого низкого качества из всех тех, которые производились в разных отраслях российской промышленности.

Также российские производители среднего и низшего звена прибегали к покупке на казахских рынках сырья низкого качества, а произведённые из него товары затем сбывали там же. Наряду с этим, российские купцы распространяли на казах- 
ских рынках русскоязычную литературу, которая становилась основным предметом для чтения в местной интеллигенции, поскольку собственных книг еще не было. Таким образом, происходила также и культурная экспансия России в Казахстане. Очевидно, что активизация российско-казахской торговли была направлена на постепенную колонизацию казахских земель.

Завоевав Казанское ханство в 1598 г., Московское царство больше не нуждалось в равноправных союзнических отношениях с казахским государством. Последнее переживало времена раздробленности, когда авторитет хана не способен был остановить противостояния между местными родами. В разных местностях все чаще начинались повстанческие движения против ханской власти, централизация Казахского ханства становилась всё более и более номинальной. В таких условиях московские власти поддерживала дипломатические отношения уже не с ханом, а с самыми могущественными из местных правителей. Также оказывалась финансовая и военная помощь отдельным повстанческим движениям, направленным на ликвидацию власти хана.

Квинтэссенцией экспансионистских устремлений самодержавия в Казахстане стал период первой четверти XVIII в., когда при правлении царя Петра I происходило утверждение основ внешнеполитического курса Российской империи. В это время в Среднюю Азию направлялись многочисленные экспедиции (как частные, так и в соответствии с царскими указами), которые имели целью осуществить детальное географическое описание этих территорий [3]. В материалах экспедиций, которые действовали на территории Казахского ханства, отмечалась якобы отсталость этой страны.

В частности, речь шла о том, что в казахском обществе царят пережитки патриархального строя, положение женщины всё ещё остается угнетённым по сравнению с мужем, земельные отношения не достигли даже феодальной стадии развития, а постоянные междоусобицы местных родов тормозят развитие государства и препятствуют ее централизации. Эти «недостатки» казахского строя характеризовались в царских документах и письмах с применением большого количества эпитетов для описания «отсталости» казахов, которая якобы обусловила то, что их государство стало объектом постоянных нападений Китайской империи, Джунгарского ханства и других сопредельных государств [13].

Необходимость «спасать» «заброшенное» Казахское ханство от военных угроз, совмещённая со стратегической заинтересованностью царского правительства в его природных ресурсах и выгодном географическом расположении, определили дальнейшую направленность российской политики в отношении этого государства. Результатом реализации последней стало включение в состав Российской империи Младшего, Среднего и Старшего жузов как составных частей Казахского ханства в 1731, 1740 и 1818 гг. соответственно.

Обзор истории российско-казахских отношений в период 1465-1731 гг. от времени основания Казахского ханства до включения Младшего жуза в состав Российской империи позволяет утверждать о периодических коренных изменениях в их характере. По моему мнению, может быть предложена такая периодизация российско-казахских отношений в указанный период в соответствии со стратегическими соображениями российских властей: 
1. 1465-1547 гг. - исключительно торговые отношения - охватывает временной промежуток от основания Казахского ханства до восшествия на московский трон Ивана Грозного. Изначально отношения между государствами складывались как партнёрские и не выходили за пределы предметной сферы торговли. В ходе торговли российская сторона проводила активные разведывательные действия с целью получения подробных сведений об особенностях политического устройства и быта казахов, а также природных условий этого региона;

2. 1547-1598 гг. - военно-союзнические отношения - период от начала правления Ивана Грозного до завоевания Сибирского ханства. Провозглашение захватнического курса в политике Московского царства способствовало интенсификации расширения его территории за счёт земель сопредельных государств. Ввиду отсутствия сильной армии царю необходимы были союзники для воплощения внешнеполитической стратегии.

Так, завоевав Казанское и Астраханское ханства, для обеспечения полного контроля над регионом московиты стали строить планы по завоеванию Сибирского ханства. Поскольку последнее значительно превосходило Москву по военной мощи, царь Иван Грозный решил прибегнуть к помощи казахов, которые также вели войны с Сибирью, но более успешно, нежели русские. Наблюдая постепенное падение Сибирского ханства под ударами казахских войск, царь больше не считал необходимым рассматривать казахов в качестве союзников. В связи с этим в 1594 г. к хану Таваккулу было направлено царское посольство с предложениями о добровольном принятии московского подданства, на что был получен решительный отказ казахов;

3. 1598-1714 гг. - перманентная поддержка отдельных родов. Ввиду активного противодействия казахов принятию московского подданства царское правительство, воспользовавшись недостаточно прочной централизованностью власти в Казахском ханстве, стало предпринимать различные действия для ослабления влиятельности общеказахских ханов. Самым распространённым из них стало оказание поддержки тем из влиятельных казахских родов, которые были опозиционно настроены к центральной власти и стремились обособиться от государства;

4. 1714-1731 гг. - переговоры с ханской властью относительно добровольного принятия российского подданства, разработка планов по захвату казахских сырьевых баз - при Петре I была разработана новая концепция российской внешней политики в соответствии с вновь обретённым статусом империи. По сравнению с предыдущим периодом, экспансионистские устремления российских властей стали выраженными более ярко и опирались на накопленный в предыдущие времена опыт.

Касательно казахов это проявлялось в направлении согласно царским указам военизированных экспедиций на территорию Казахского и пограничных с ним Хивинского и Бухарского ханств. Помимо этого, состоявшее в торговых связях с Российской империей Джунгарское ханство своими перманентными нападениями ослабляло казахов. Это привело к началу процессов по «добровольному» принятию ими российского подданства в 1731 г.

Выводы. Таким образом, политика России в отношении Казахского ханства на протяжении XV - XVIII вв. претерпевала качественные изменения, связанные с трансформацией стратегических целей самодержавия в среднеазиатском регионе. 
После того, когда отпала потребность в сильном союзнике, царизм прибегнул к постепенной колонизации экономически и политически выгодных казахских территорий через дискредитацию их власти, вмешательства во внутриполитические процессы и побуждения ханской власти к принятию российского подданства.

Изучение этого опыта представляется крайне важным для всех государств, против которых Российской Федерацией в настоящее время развернута гибридная война (в том числе, для Украины), поскольку это предоставит возможность прогнозировать поведение государства-агрессора и организовывать эффективное противодействие его экспансионистским действиям.

\section{Лuтература}

1. Аполлова Н.Г. Экономические и политические связи Казахстана с Россией в XVIII - начале XIX в. / Н.Г. Аполлова. М. : Изд-во АН СССР, 1960. 430 с.

2. Арапов Д.Ю. Бухарское ханство в русской востоковедческой историографии / Д.Ю. Арапов. М. : Изд-во Моск. ун-та, 1981. 128 с.

3. Басин В.Я. Казахстан в системе внешней политики России в первой половине XVIII века / В.Я. Басин // Казахстан в XV - XVIII веках (Вопросы социально-политической истории). Алма-Ата : «Наука», 1969. С. 50-145.

4. Басин В.Я. Россия и казахские ханства в XVI - XVIII вв. / В.Я. Басин. Алма-Ата : Изд-во «Наука» Казахской ССР, 1971. 275 с.

5. Иванов А.Ю. Политико-правовые предпосылки включения Казахстана в состав Российской империи (1714-1818 гг.) / А.Ю. Иванов // Legea i via a. 2020. № 1. С. 43-47.

6. История СССР : учеб. для студ. ист. фак. пед. ин-тов. 4-е изд., испр. М. : Просвещение, 1979. Ч. I. 607 c.

7. История СССР с древнейших времён до наших дней. Т. II. Борьба народов нашей страны за независимость в XIII - XVII вв. Образование единого русского государства. М. : Изд-во «Наука», $1966.631 \mathrm{c}$.

8. Іванов О.Ю. Ідеологічні та політико-правові засади російської експансії в Казахстані (1714 р. перша половина XIX ст.) / О.Ю. Іванов / / Часопис Київського університету права. 2020. № 1. С. 41-46.

9. Іванов О.Ю. Ідеологія російського експансіонізму як історико-правовий феномен / О.Ю. Іванов // Часопис Київського університету права. 2018. № 4. С. 36-41.

10. Краткая история СССР. Ч. 1. Л. : Изд-во «Наука», Ленинградское отделение, 1972.440 с.

11. Масанов Э.А. Из историиэтнографического изучения казахского народав России (XV-XVIIвв.)/ Э.А. Масанов. М. : «Наука», 1964.10 с.

12. Махашев Х. Проблемы вхождения Казахстана в Россию в дореволюционно-буржуазной историографии / X. Махашев // Проблемы истории русско-казахских взаимоотношений в XVIII - начале ХХ веков. Алма-Ата, 1980. С. 107-114.

13. Сабырханов А. Исторические предпосылки ликвидации ханской власти в Казахстане / А. Сабырханов // Казахстан в эпоху феодализма (проблемы этнополитической истории). Алма-Ата : «Наука» КазССР. 1981. С. 149-163.

14. Советский Союз. Геогр. описание в 22 -х томах. Казахстан. М. : «Мысль», 1970. 408 с. 


\section{Аннотация}

Иванов А. Ю. Казахское ханство как объект российского геополитического влияния (14651731 гг.): историко-правовой аспект. - Статья.

В статье рассматриваются различные аспекты историко-правовой реальности середины XV - начала XVIII вв., связанные с формированием политического курса Московского государства относительно Казахского ханства. Прослеживается динамика формирования и реализации экспансионистских устремлений московской монархии касательно казахской государственности от момента её зарождения в 1465 г. и до начала ликвидации в 1731 г.

Доказано, что с конца XV в. Московское царство, а затем и Российская империя взяли курс на дестабилизацию политической ситуации в Казахском ханстве. Особое внимание уделяется анализу особенностей сбора и накопления разноплановых и обширных сведений о казахах российской стороной, использованию московской стороной несовершенств государственного строя Казахского ханства с целью его дискредитации. Подробно освещены особенности установления российского присутствия в среднеазиатских степях, а также использованные при этом средств политического, экономического и культурного воздействия.

Показана также динамика изменения политического курса Московского государства относительно казахов в связи с изменениями его стратегических интересов на различных этапах истории, исходя из чего автором статьи разработана и обоснована авторская периодизация этого процесса. Отмечается, что квинтэссенцией экспансионистских устремлений самодержавия в Казахстане стал период первой четверти XVIII в., когда при правлении Петра I происходило утверждение основ внешнеполитического курса Российской империи.

Автор приходит к выводу, что царизм прибегнул к постепенной колонизации экономически и политически выгодных территорий Казахского ханства путём дискредитации его власти, вмешательства во внутриполитические процессы и дальнейшего побуждения ханской власти к принятию российского подданства. Постепенная утрата суверенитета казахским государством в первой половине XVIII в. объясняется как следствие планомерного и многовекторного деструктивного воздействия московских монархов. Изучение этого опыта представляется особенно актуальным в современных условиях гибридной войны, которую ведёт Российская Федерация против международного сообщества.

Ключевые слова: казахи, Московское царство, Российская империя, экспансия, стратегические интересы.

\section{Анотація}

Іванов О. Ю. Казахське ханство як об’єкт російського геополітичного впливу (1465-1731рр.): історико-правовий аспект. - Стаття.

У статті розглядаються різні аспекти історико-правової реальності середини XV - початку XVIII ст., пов'язані з формуванням політичного курсу Московської держави щодо Казахського ханства. Простежується динаміка формування і реалізації експансіоністських устремлінь московської монархії щодо казахської державності від моменту її зародження в 1465 р. і до початку ліквідації в 1731 р. Доведено, що з кінця XV ст. Московське царство, а потім і Російська імперія взяли курс на дестабілізацію політичної ситуації в Казахському ханстві.

Особлива увага приділяється аналізу особливостей збору та накопичення різнопланових і обширних відомостей про казахів російською стороною. Особливу увагу приділено використанню московською стороною недосконалостей державного ладу Казахського ханства з метою його дискредитації. Детально висвітлено особливості встановлення російської присутності в середньоазійських степах, а також використані при цьому засоби політичного, економічного і культурного впливу.

Показана також динаміка зміни політичного курсу Московської держави щодо казахів у зв'язку зі змінами її стратегічних інтересів на різних етапах історії, на основі чого автором статті розроблена і обгрунтована авторська періодизація цього процесу. Зазначається, що квінтесенцією експансіоністських устремлінь самодержавства в Казахстані став період першої чверті XVIII ст., коли за правління Петра I відбувалося утвердження засад зовнішньополітичного курсу Російської імперії.

Автор доходить висновку, що царизм вдавався до поступової колонізації економічно й політично вигідних територій Казахського ханства шляхом дискредитації його влади, втручання у внутрішньополітичні процеси і подальшого спонукання ханської влади до прийняття російського підданства. Поступова втрата суверенітету казахською державою в першій половині XVIII ст. пояснюється як наслідок планомірного і багатовекторного деструктивного впливу московських монархів. Вивчення цього досвіду є особливо актуальним в сучасних умовах гібридної війни, яку веде Російська Федерація проти міжнародного співтовариства.

Ключові слова: казахи, Московське царство, Російська імперія, експансія, стратегічні інтереси. 


\section{Summary}

Ivanov O. Yu. The Kazakh Khanate as the object of the Russian geopolitical influence (1465-1731): historical and legal aspect. - Article.

The article deals with various aspects of historical and legal reality of the middle of the XV - beginning of the XVIII centuries, related to the formation of the political course of the Moscow state concerning the Kazakh Khanate. Dynamics of formation and realization of expansionist aspirations of the Moscow monarchy concerning the Kazakh statehood from the moment of its foundation in 1465 up to the beginning of its liquidation in 1731 is traced. It is proved that from the end of the XV century the Moscow kingdom, and then the Russian empire took the course on destabilization of political situation in the Kazakh Khanate. Special attention is paid to the analysis of peculiarities of collection and accumulation of diverse and extensive information about Kazakhs by the Russian side.

Special attention is paid to the use by the Moscow side of the imperfections of the state system of the Kazakh Khanate in order to discredit it. The peculiarities of the establishment of the Russian presence in the Central Asian steppes, as well as the means of political, economic and cultural influence used in this process are highlighted in details. Dynamics of change of political course of the Moscow state concerning Kazakhs in connection with changes of its strategic interests at different stages of history is also shown, on the basis of which the author of the article developed and substantiated the author's periodization of this process.

It is noted that the quintessence of the expansionist aspirations of the autocracy in Kazakhstan was the period of the first quarter of the XVIII century, when under the reign of Peter the Great there was an assertion of the foundations of the foreign policy of the Russian Empire. The author concludes that Tsarism resorted to the gradual colonization of economically and politically advantageous territories of the Kazakh Khanate by discrediting its power, interfering in domestic political processes and further encouraging the Khan's power to accept Russian citizenship.

Gradual loss of sovereignty by the Kazakh state in the first half of the XVIII century is explained as a consequence of systematic and multi-vector destructive influence of Moscow monarchs. The study of this experience is particularly relevant in the current conditions of the hybrid war waged by the Russian Federation against the international community.

Key words: Kazakhs, Moscow Tsardom, Russian Empire, expansion, strategic interests. 